\title{
Chemoselective Lactonization of Renewable Succinic Acid with Heterogeneous Nanoparticle Catalysts
}

\author{
Keiko Yakabi, ${ }^{\dagger}$ Alexandra Jones, ${ }^{\dagger}$ Antoine Buchard, ${ }^{\ddagger}{ }^{\oplus 0}$ Alberto Roldan, ${ }^{\dagger}$ and Ceri Hammond ${ }^{*}, \dagger$ \\ ${ }^{\dagger}$ Cardiff Catalysis Institute, School of Chemistry, Cardiff University, Park Place, Cardiff CF10 3AT, United Kingdom \\ ${ }^{\ddagger}$ Centre for Sustainable Chemical Technologies, Department of Chemistry, University of Bath, Bath BA2 7AY, United Kingdom
}

\section{Supporting Information}

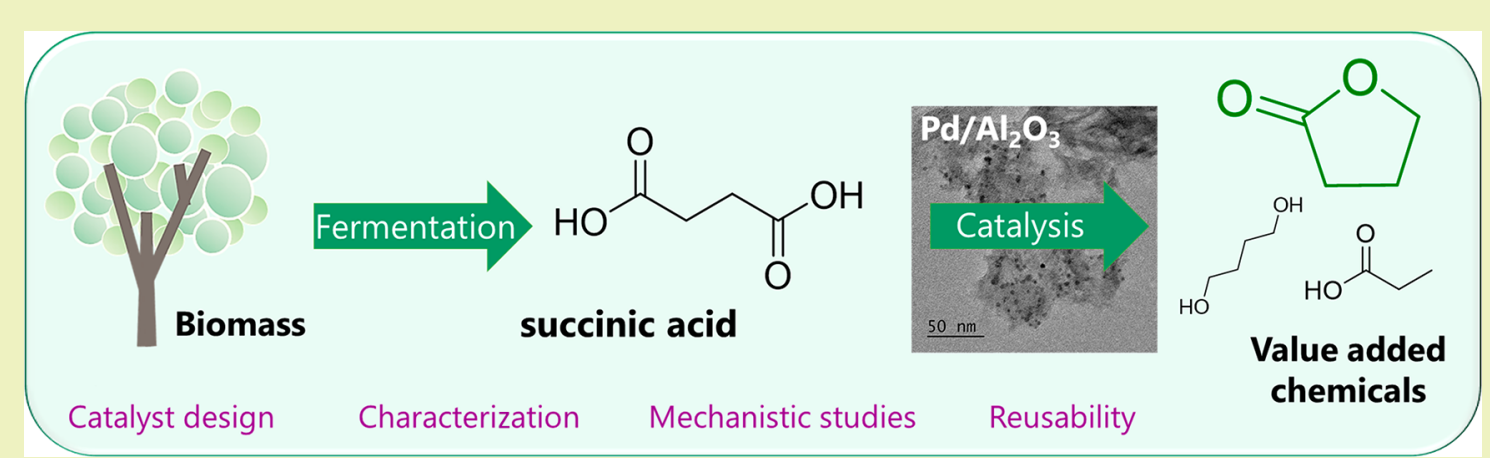

ABSTRACT: The production of chemicals from renewable resources, resulting in the establishment of biorefineries, represents a challenge of increasing importance. Here we show that succinic acid, a C4 compound increasingly being produced on a kiloton scale by the microbial fermentation of sugar, can be selectively converted into a variety of important chemicals. Optimal performance in terms of activity, selectivity and reusability is observed with $\mathrm{Al}_{2} \mathrm{O}_{3}$-supported $\mathrm{Pd}$ nanoparticles, which mediate the selective, hydrogenative lactonization of succinic acid to $\gamma$-butyrolactone at $>90 \%$ selectivity, even at high levels of conversion $(<70 \%)$. Through a variety of kinetic, spectroscopic and microscopic studies, preliminary structure-activity relationships are presented, and the roles of the reaction conditions, the choice of metal and the nature of the support in terms of guiding the overall process selectivity, are also investigated. On a broader level, these studies demonstrate the suitability of succinic acid to act as a platform for renewable chemical production in future biorefineries.

KEYWORDS: Biomass, Heterogeneous catalysis, Nanoparticles, Hydrogenation, Monomers

\section{INTRODUCTION}

Over the last century, the world has become increasingly dependent on fossil feedstock for the production of fuels, base chemicals, and commodities, including fibers, pharmaceuticals, detergents, plastics, pesticides, fertilizers, lubricants, solvents and much more. ${ }^{1,2}$ In fact, over $99 \%$ of all plastics are produced from chemicals sourced from fossil fuels. ${ }^{3}$ However, the decreasing availability and volatile pricing of crude oil, the geopolitical and economic issues relating to its unequal distribution, coupled to the harmful nature of the byproducts generated through its consumption, have stimulated the chemical society to search for alternative sources for fuels and chemicals. ${ }^{4-6}$ Although a variety of renewable vectors hold potential for energy production, the production of chemicals requires carbon-based resources. When considering alternative carbon-based raw materials for the chemical industry, options are mainly limited to plants or atmospheric carbon $\left(\mathrm{CO}_{2}\right)$. Although routes exist for converting atmospheric $\mathrm{CO}_{2}$ to liquid products, several technical limitations currently impact the feasibility of these approaches. Thus, biorenewables, such as lipids, starches and celluloses, are emerging as the most sustainable class of feedstock for chemicals.
In fact, the high functionality and chemical diversity of biorenewables makes them an excellent raw material for the production of value-added chemicals and polymers, ${ }^{10,11}$ Given their high oxygen content and functionality, the utilization of biomass as industrial feedstock also eliminates the requirement for some functional group insertions, thereby reducing the total number of processing steps required. Moreover, it permits the production of higher carbon chain length molecules (C4+) that are not typically present in other emerging feedstock, such as shale gas. As cellulose-based derivatives account for $60-90 \%$ (by weight) of all biorenewable material, they therefore represent the most viable and sustainable source of carbon chemical production. Of particular interest is cellulose derived from second-generation biomass and energy crops, ${ }^{12}$ which exhibits several advantages including (1) an ability to be grown on marginal land, (2) higher levels of productivity in terms of sugar produced per acre and per unit time and (3) lower lifecycle $\mathrm{CO}_{2}$ emissions. For example, the lifecycle $\mathrm{CO}_{2}$

Received: July 13, 2018

Revised: September 26, 2018

Published: October 29, 2018 
emission from energy cane is 3-4 times lower than those of corn and sugar cane, and 7 times lower than that of gasoline. Moreover, second-generation biomass does not compete with food sources, unlike other first-generation biomass, such as bioethanol. $^{13}$

Among possible strategies for converting renewables into chemicals, catalytic methodologies offer several advantages, particularly in the context of process intensification. Of these, one of the most promising involves the catalytic conversion of various "platform" molecules, which are themselves obtained via controlled depolymerization or fermentation of cellulose. ${ }^{14}$ Examples of such platform molecules include glucose, fructose, 5-hydroxymethylfurfural, 2,5-furandicarboxylic acid, 3-hydroxypropionic acid, levulinic acid and glycerol, among others. ${ }^{15,16}$ In fact, the catalytic conversion of several of these platforms has received an enormous amount of attention over the past decade. However, despite the surge of interest in renewable chemical production from these platform molecules, a number of other platforms with high potential have received relatively little attention. A key example is succinic acid (SA). Classically obtained by the hydrogenation of butane-derived maleic anhydride, recent breakthroughs in biotechnology mean renewable SA is now being produced via the fermentation of glucose on a kilotonne scale by several companies. ${ }^{17-19}$ However, despite the advanced stage of these production processes, and its widely accepted high potential as a platform molecule, the catalytic conversion of succinic acid to value added products has received scant attention, despite the plethora of products that can in principle be obtained from it. In fact, an important number of commodity chemicals, ${ }^{20,21}$ including 1,4-butanediol (BDO), tetrohydrofuran (THF) and $\gamma$-butyrolactone (GBL), can all be obtained from succinic acid under the guidance of a suitable catalytic material (Figure 1).

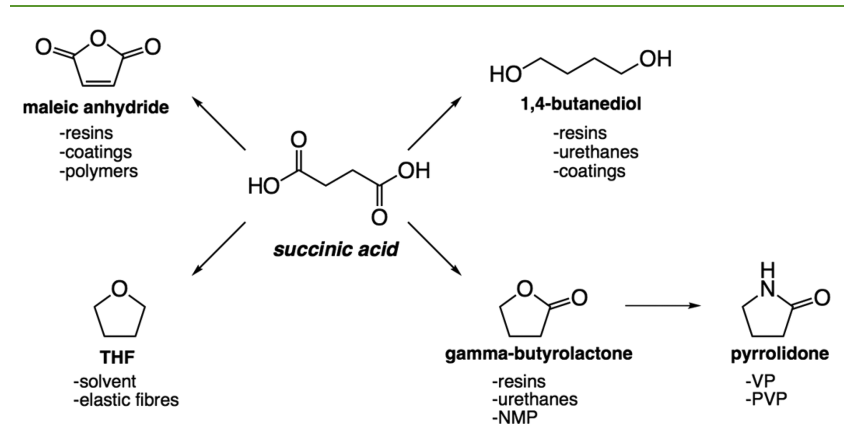

Figure 1. Possible routes by which renewable succinic acid can be further converted into value added products under the guidance of heterogeneous catalysts.

Among these processes, the conversion of succinic acid to GBL has been identified as one of the most technologically attractive, as it opens up routes toward various commodity compounds and additional downstream monomers, such as pyrrolidone. $^{15,22}$

To the best of our knowledge, however, only a handful of reports concerning the catalytic conversion of succinic acid can be found in the open literature. ${ }^{23-28}$ In each of these previous studies, the reductive valorization of SA was investigated. Although classical hydrogenation catalysts, such as supported $\mathrm{Ru}$ and $\mathrm{Pd}$ nanoparticles, have been shown to be active heterogeneous catalysts for this reaction, very harsh conditions, such as high reaction temperatures $\left(>240{ }^{\circ} \mathrm{C}\right)$ and high pressures $(<80$ bar) have previously been required (Table
S1). ${ }^{29-33}$ Even at these conditions, the productivities of the processes are also rather low. Moreover, and more crucially in the context of process intensification, it is clear that investigation of the overall reaction network, and particularly the selective production of one particular reaction product, has not yet been achieved. In fact, in previous reports a variety of reaction products are typically observed, particularly at elevated levels of productivity. ${ }^{34-36}$ We note that although achieving high levels of selectivity during the upgrading of biorenewables is especially challenging, given their high levels of functionality and reactivity, it is an essential task considering the economic and energetic cost of downstream separation. As such, development of a catalytic system that exhibits both high selectivity and productivity at mild conditions has not yet been achieved.

Herein, we demonstrate that various supported hydrogenation catalysts, such as $\mathrm{Pd} / \mathrm{Al}_{2} \mathrm{O}_{3}$ and $\mathrm{Ru} / \mathrm{Al}_{2} \mathrm{O}_{3}$, are able to convert SA selectivity to $\mathrm{GBL}$ at relatively mild conditions (140-170 ${ }^{\circ} \mathrm{C}, 15-30$ bar $\mathrm{H}_{2}$ ). Although commercially available catalysts demonstrate high levels of performance, optimal performance in terms of activity and selectivity to GBL is achieved with $5 \mathrm{wt} \% \mathrm{Pd} / \mathrm{Al}_{2} \mathrm{O}_{3}$, prepared by coprecipitation, which results in GBL being produced at greater than $90 \%$ selectivity even at high levels of conversion $(<70 \%)$. Interestingly, the choice of active metal dramatically impacts the overall selectivity of the reaction under otherwise identical conditions, with $\mathrm{Ru}$ resulting in comparable to selectivity to both GBL and propionic acid (PA), whereas utilization of Pd results in almost exclusive production of GBL. Kinetic, spectroscopic and microscopic studies indicate that overall performance depends on the reaction conditions, the composition of the catalyst (choice of metal, metal loading and nature of support), in addition to the method of catalyst preparation.

\section{RESULTS AND DISCUSSION}

Optimization of Reaction Conditions. The catalytic hydrogenation of SA can result in a variety of important commodity chemicals, including THF, GBL and BDO, among others. Given how the reaction conditions can impact overall activity and selectivity, the choice of reaction conditions including time, temperature, pressure and catalyst loading require optimization for the highest levels of performance to be achieved. Given the reported ability of Ru nanoparticles to hydrogenate $\mathrm{SA}$, optimization studies were performed with a commercially available $\mathrm{Ru} / \mathrm{Al}_{2} \mathrm{O}_{3}$ catalyst (Sigma-Aldrich, $5 \mathrm{wt}$ $\% \mathrm{Ru}$, reduced, henceforth denoted $\left.5 \mathrm{Ru} / \mathrm{Al}_{2} \mathrm{O}_{3(\mathrm{COM})}\right)$. To identify the optimal temperature regime of the reaction, a number of kinetic experiments were performed at various temperatures and times, under otherwise identical conditions (Figure 2, Left). Increasing the time ( $4 \mathrm{~h}$ vs $1 \mathrm{~h}$ ) and the temperature $\left(140-270{ }^{\circ} \mathrm{C}\right)$ of the reaction results in an increased amount of product being obtained from SA. Under these conditions, a maximum product yield of $85 \%$ was achieved, at temperatures of 230 and $270{ }^{\circ} \mathrm{C}$ for 4 and $1 \mathrm{~h}$ reactions, respectively. Determination of the effective rate constant at the first hour of each reaction (eq 1) allowed a preliminary Arrhenius expression for $5 \mathrm{Ru} / \mathrm{Al}_{2} \mathrm{O}_{3(\mathrm{COM})}$ to be generated (Figure 2, Right). This revealed the activation energy of the system to be $78.9 \mathrm{~kJ} \mathrm{~mol}^{-1}$. Further control experiments revealed that in the absence of catalyst and $\mathrm{H}_{2}$, no conversion of SA was observed (Table S2), confirming the 

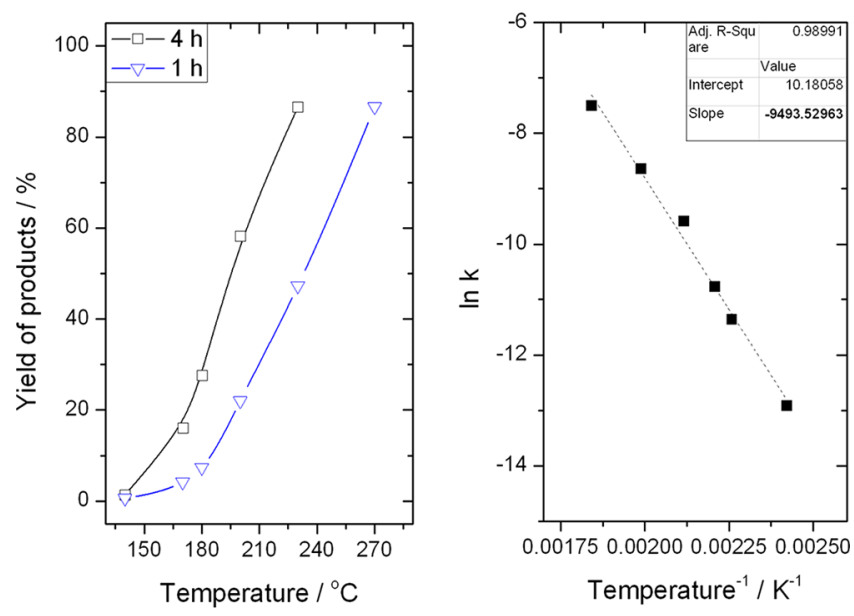

Figure 2. (Left) Total product yield obtained from the hydrogenation of succinic acid under the influence of $5 \mathrm{Ru} / \mathrm{Al}_{2} \mathrm{O}_{3}$ (COM) at various reaction temperatures for $1 \mathrm{~h}$ (triangles) and $4 \mathrm{~h}$ of reaction time (squares). (Right) Arrhenius plot for $5 \mathrm{Ru} / \mathrm{Al}_{2} \mathrm{O}_{3(\mathrm{COM})}$ between 140 and $270{ }^{\circ} \mathrm{C}$, determined from the effective rate constant at $1 \mathrm{~h}$ of reaction at various temperatures. Reaction conditions: $15 \mathrm{~mL}$ of $0.2 \mathrm{M}$ succinic acid in 1,4-dioxane, $1 \mathrm{~mol} \%$ of Ru respect to succinic acid, 15 bar $\mathrm{H}_{2}$.

heterogeneous and hydrogenative nature of the reaction, respectively.

$$
k_{\text {eff }}=\frac{-\ln (1-\text { conversion })}{\text { time }}
$$

To gain better insight of how the choice of temperature and time influence the overall reaction performance, the product distribution obtained after $4 \mathrm{~h}$ of reaction between 170 and $230{ }^{\circ} \mathrm{C}$ was investigated in greater detail. Under the influence of $5 \mathrm{Ru} / \mathrm{Al}_{2} \mathrm{O}_{3}$ (COM), SA was primarily converted to $\mathrm{GBL}$ and PA. However, smaller amounts of butyric acid (BA) were also observed in solution, and traces ( $<1 \mathrm{~mol} \%$ carbon) of $\mathrm{CO}_{2}$ were detected in the gas phase by GC-FID (methanizer) and $\mathrm{GC}-\mathrm{MS}$ analysis. In total, these products and the remaining unconverted substrate accounted for $>95 \%$ of the carbon balance in each of these reactions. Preliminary analysis indicates that GBL, the desired reaction product, is preferentially observed at lower temperatures. However, selectivity during heterogeneous catalysis is always a function of conversion. ${ }^{39}$ Consequently, more detailed analysis was performed by repeating reactions at 170,200 and $230{ }^{\circ} \mathrm{C}$ for various periods of time, and plotting the GBL selectivity observed at several values of total product yield (iso-conversion analysis) (Figure 3, Right). Interestingly, at each reaction temperature, GBL selectivity is almost invariant at all levels of product yield, indicating that formation of GBL and PA are not related with $5 \mathrm{Ru} / \mathrm{Al}_{2} \mathrm{O}_{3(\mathrm{COM})}$ i.e., consecutive conversion of these products is unlikely. However, it is clear that GBL selectivity is always higher at lower temperatures at all overlapping levels of product yield, reaching a maximum selectivity of $64 \%$ with $5 \mathrm{Ru} / \mathrm{Al}_{2} \mathrm{O}_{3(\mathrm{COM})}$ at $170{ }^{\circ} \mathrm{C}$. Given the potential of a SA-GBL process, ${ }^{15}$ in addition to the desire to maximize process selectivity during biomass conversion, all further experiments were conducted at $170{ }^{\circ} \mathrm{C}$, as this provides the best level of intrinsic selectivity to GBL.

Control experiments performed at different catalyst loadings reveal a linear relationship between mass of catalyst and initial rate of reaction, up to catalyst loadings of $2 \mathrm{~mol} \% \mathrm{Ru}$ (Figure
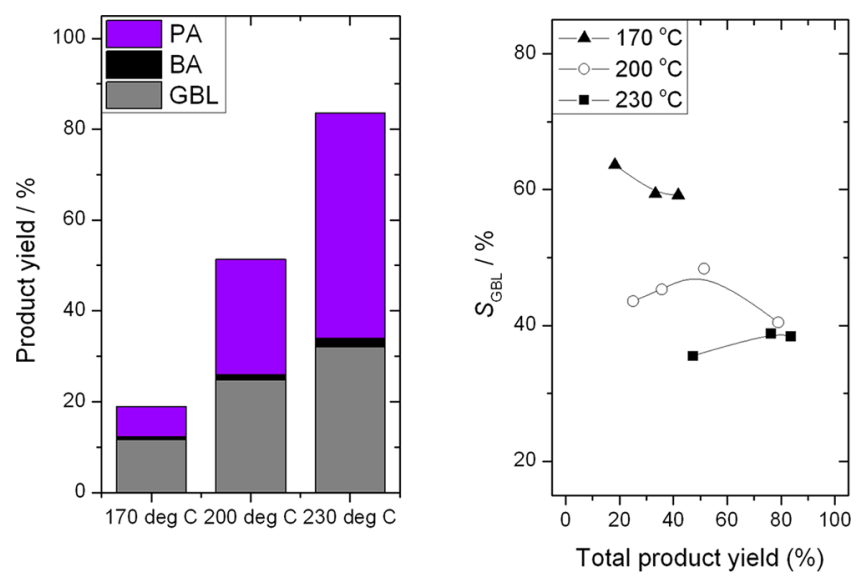

Figure 3. (Left) Product distribution obtained following the hydrogenation of succinic acid by $5 \mathrm{wt} \% \mathrm{Ru} / \mathrm{Al}_{2} \mathrm{O}_{3}(\mathrm{COM})$ at various reaction temperatures for $4 \mathrm{~h}$ (triangles). (Right) Iso-conversion profile obtained during the hydrogenation of succinic acid between 170 and $230{ }^{\circ} \mathrm{C}$ with $5 \mathrm{Ru} / \mathrm{Al}_{2} \mathrm{O}_{3(\mathrm{COM})}$. Reaction conditions: $15 \mathrm{~mL}$ of $0.2 \mathrm{M}$ succinic acid in 1,4-dioxane, $1 \mathrm{~mol} \%$ of $\mathrm{Ru}$ with respect to succinic acid, 15 bar $\mathrm{H}_{2}$ at the stated working temperature.

4, Left). However, at the highest levels of catalyst loading (5 mol \%) the reaction rate deviates from linear, indicating
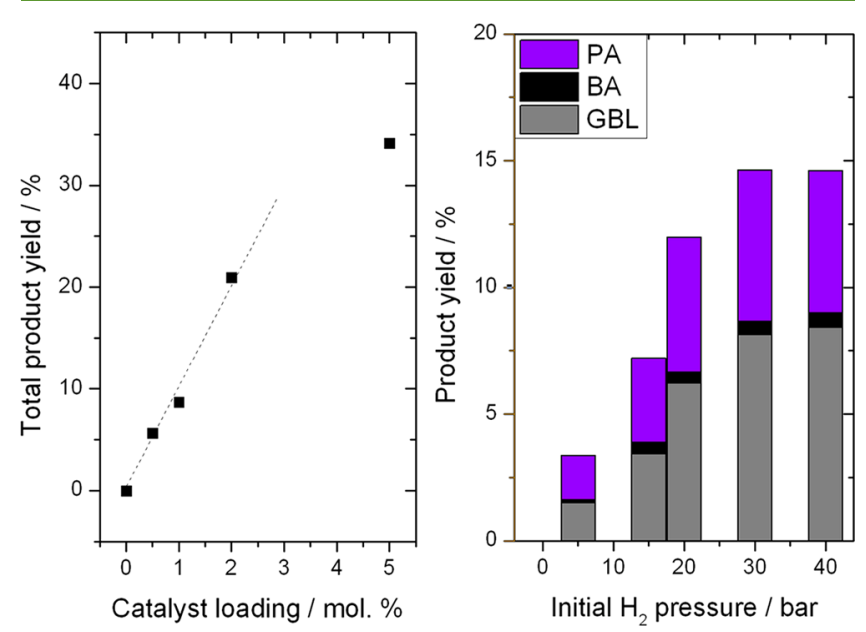

Figure 4. (Left) Total product yield obtained during the hydrogenation of succinic acid by $5 \mathrm{Ru} / \mathrm{Al}_{2} \mathrm{O}_{3}$ (COM) at various catalyst loadings, represented as mol \% of $\mathrm{Ru}$ with respect to the substrate (squares). (Right) Impact of $\mathrm{H}_{2}$ pressure during the hydrogenation of succinic acid by $5 \mathrm{Ru} / \mathrm{Al}_{2} \mathrm{O}_{3(\mathrm{COM})}$ at a catalyst loading of $1 \mathrm{~mol} \%$ and $2 \mathrm{~h}$ of reaction time. Reaction conditions: $15 \mathrm{~mL}$ of $0.2 \mathrm{M}$ succinic acid in 1,4-dioxane, $1 \mathrm{~mol} \%$ of $\mathrm{Ru}$ with respect to succinic acid, 170 ${ }^{\circ} \mathrm{C}$ and various pressures of $\mathrm{H}_{2}$.

potential contributions from transport limitations at the highest levels of catalyst loading. Further control experiments also reveal that activity could also be improved by increasing the $\mathrm{H}_{2}$ pressure from 5 to 30 bar (Figure 4, Right). However, above this level of pressure, no increase in reaction rate is observed, indicating the presence of sufficient $\mathrm{H}_{2}$ in the reaction medium. Importantly, selectivity to GBL is not overly affected by modifying the reaction pressure under the influence of $5 \mathrm{Ru} / \mathrm{Al}_{2} \mathrm{O}_{3 \text { (COM) }}$, and comparable selectivity to both GBL and $\mathrm{PA}$ is always observed across the entire $\mathrm{H}_{2}$ pressure range. Thus, it is clear that optimal performance in terms of activity, GBL selectivity and process favorability is achieved at $170{ }^{\circ} \mathrm{C}$, 
$\mathrm{H}_{2}$ pressures of $30 \mathrm{bar}$, and catalyst loadings of $2 \mathrm{~mol} \%$ and lower.

Catalyst Design Studies. Alongside the reaction conditions, the properties of a solid, such as the choice of metal, its level of loading on the support and the method of preparation, can dramatically impact its overall performance as a heterogeneous catalyst. Accordingly, the design of more active and selective heterogeneous catalysts is an essential requirement during the development of new chemical processes. Given the high activity observed over $\mathrm{Al}_{2} \mathrm{O}_{3}$-supported $\mathrm{Ru}$ nanoparticles, a variety of analogous $\mathrm{Al}_{2} \mathrm{O}_{3}$-supported metal nanoparticles were screened for reactivity at the optimal conditions identified for catalyst screening $\left(170{ }^{\circ} \mathrm{C}, 30\right.$ bar $\mathrm{H}_{2}$, $2 \mathrm{~mol} \%$ catalyst relative to $\mathrm{SA}$ ). Initial catalysts were all prepared by coprecipitation, as this is known to permit the production of well-dispersed nanoparticles along with the generation of high surface area supports, both critical factors during heterogeneous catalysis. ${ }^{38}$ Initial metal loadings of $2 \mathrm{wt}$ $\%$ were targeted and prior to reaction, all samples were reduced at $200{ }^{\circ} \mathrm{C}$ for $3 \mathrm{~h}$, under a flow of $5 \% \mathrm{H}_{2} / \mathrm{Ar}$. As can be seen (Figure 5, Left), catalytic activity for the hydrogenation of SA
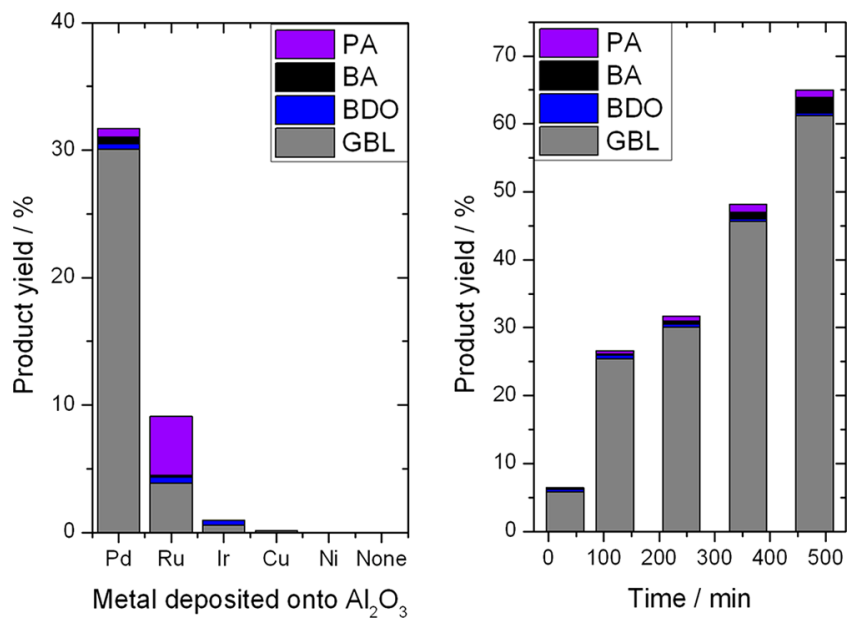

Figure 5. (Left) Product distribution achieved for various 2 wt \% metal-doped $\mathrm{Al}_{2} \mathrm{O}_{3}$ catalysts prepared by coprecipitation, during the hydrogenation of succinic acid. (Right) Time online analysis for the hydrogenation of succinic acid over 2 wt $\% \mathrm{Pd} / \mathrm{Al}_{2} \mathrm{O}_{3}$ prepared by coprecipitation. Reaction conditions: $15 \mathrm{~mL}$ of $0.2 \mathrm{M}$ succinic acid in 1,4-dioxane, $2 \mathrm{~mol} \%$ of metal with respect to succinic acid, $170{ }^{\circ} \mathrm{C}$, 30 bar $\mathrm{H}_{2}, 4 \mathrm{~h}$.

is observed when $\mathrm{Pd}$ or $\mathrm{Ru}$ are deposited onto $\mathrm{Al}_{2} \mathrm{O}_{3}$. In contrast, other established hydrogenation catalysts (e.g., $\mathrm{Cu}, \mathrm{Ni}$ and Ir) are substantially less active, or not active at all. Although $2 \mathrm{Ru} / \mathrm{Al}_{2} \mathrm{O}_{3}(\mathrm{COP})$ is lower in activity than the

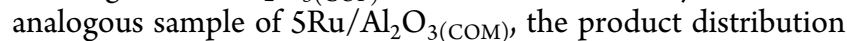
is comparable for both catalysts, with both GBL and PA observed at similar levels of selectivity. However, 2Pd/ $\mathrm{Al}_{2} \mathrm{O}_{3}$ (COP) is over three times as active as the analogous sample of $2 \mathrm{Ru} / \mathrm{Al}_{2} \mathrm{O}_{3(\mathrm{COP})}$, indicating Pd to be a more effective catalytic element for SA hydrogenation. More importantly in the context of process intensification, the observed level of GBL selectivity also improves dramatically when $\mathrm{Pd}$ is deposited onto $\mathrm{Al}_{2} \mathrm{O}_{3}$. Indeed, $2 \mathrm{Pd} / \mathrm{Al}_{2} \mathrm{O}_{3}(\mathrm{COP})$ exhibits a GBL selectivity of $95 \%$ at a total product yield level of $32 \%$. To determine if high selectivity to GBL could be maintained at higher levels of yield, extended time online analysis of $2 \mathrm{Pd} /$ $\mathrm{Al}_{2} \mathrm{O}_{3 \text { (COP) }}$ was performed. As can be seen (Figure 5, Right), high selectivity (>90\%) to GBL is maintained even at substantially higher levels of product yield $(<60 \%$ product yield after $480 \mathrm{~min}$ of reaction). Consequently, in addition to being three times more active than the analogous $2 \mathrm{Ru}$ / $\mathrm{Al}_{2} \mathrm{O}_{3 \text { (COP) }}$ sample, $2 \mathrm{Pd} / \mathrm{Al}_{2} \mathrm{O}_{3 \text { (COP) }}$ is also twice as selective, even at high levels of conversion. Thus, $2 \mathrm{Pd} / \mathrm{Al}_{2} \mathrm{O}_{3(\mathrm{COP})}$ clearly represents the most suitable catalyst for $\mathrm{SA}$ valorization.

To gain an understanding of structure-function relationships with $2 \mathrm{Pd} / \mathrm{Al}_{2} \mathrm{O}_{3(\mathrm{COP})}$, analogous samples with different metal loadings, and different methods of preparation, were investigated. Impregnation of $2 \mathrm{wt} \% \mathrm{Pd}$ onto commercially available $\gamma-\mathrm{Al}_{2} \mathrm{O}_{3}$ (henceforth $2 \mathrm{Pd} / \mathrm{Al}_{2} \mathrm{O}_{3(\mathrm{IMP})}$ ) results in very poor levels of activity and selectivity being observed, even after reductive pretreatment $\left(200{ }^{\circ} \mathrm{C}, 5 \% \mathrm{H}_{2} / \mathrm{Ar}, 3 \mathrm{~h}\right.$ ) (Figure 6,
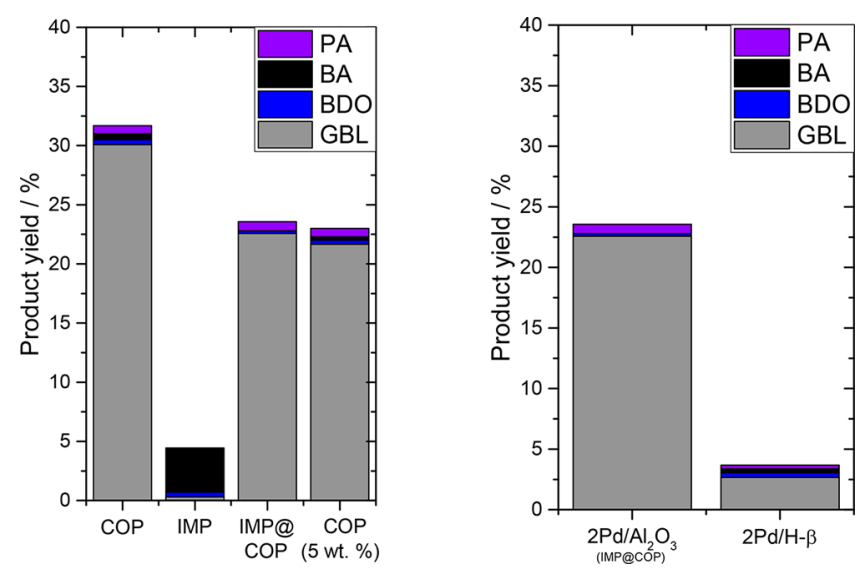

Figure 6. (Left) Product distribution achieved for various $\mathrm{Pd} / \mathrm{Al}_{2} \mathrm{O}_{3}$ catalysts prepared by coprecipitation (COP), impregnation (IMP), impregnation on coprecipitated $\mathrm{Al}_{2} \mathrm{O}_{3}$ (IMP@COP), comprising $2 \mathrm{wt}$ $\%$ metal unless otherwise stated. (Right) Product distribution obtained for 2 wt \% Pd supported on $\mathrm{Al}_{2} \mathrm{O}_{3(\mathrm{COP})}$ and $\mathrm{H}-\beta$. Reaction conditions: $15 \mathrm{~mL}$ of $0.2 \mathrm{M}$ succinic acid in 1,4-dioxane, $2 \mathrm{~mol} \%$ of $\mathrm{Pd}$ with respect to succinic acid, $170{ }^{\circ} \mathrm{C}, 30$ bar $\mathrm{H}_{2}, 4 \mathrm{~h}$.

Left). However, when 2 wt \% of Pd was impregnated onto a sample of $\mathrm{Al}_{2} \mathrm{O}_{3}$ that was itself prepared by coprecipitation (2Pd/ $\left.\mathrm{Al}_{2} \mathrm{O}_{3 \text { (IMP@COP) }}\right)$, similar levels of performance to $2 \mathrm{Pd}$ / $\mathrm{Al}_{2} \mathrm{O}_{3 \text { (COP) }}$ were observed, clearly demonstrating impregnation to be a valid method of preparation. Taking into account both impregnated results, it is clear that the properties of the support can dramatically alter performance of the catalyst. Characterization of both $\mathrm{Al}_{2} \mathrm{O}_{3}$ materials (commercial and coprecipitated) by XRD (SI Figure S1) and porosimetry (SI Table S3) revealed the very different nature of coprecipitated $\mathrm{Al}_{2} \mathrm{O}_{3}$ with respect to the commercial material. For instance, the XRD pattern of $\mathrm{Al}_{2} \mathrm{O}_{3}$ prepared by coprecipitation method is consistent with a pseudoboehmite phase of $\mathrm{Al}_{2} \mathrm{O}_{3}$, ${ }^{39}$ which possesses a much larger surface area than that of commercially available $\gamma-\mathrm{Al}_{2} \mathrm{O}_{3}$ (245 vs $93 \mathrm{~m}^{2} \mathrm{~g}^{-1}$, respectively). Analysis of the textural properties of both materials following deposition of $\mathrm{Pd}\left(2 \mathrm{Pd} / \mathrm{Al}_{2} \mathrm{O}_{3 \text { (IMP@COP) }}\right.$ and $\left.2 \mathrm{Pd} / \mathrm{Al}_{2} \mathrm{O}_{3 \text { (IMP) }}\right)$ revealed that improved porosity for the boehmite phase was retained even after deposition of the metal (224 vs $\left.85 \mathrm{~m}^{2} \mathrm{~g}^{-1}\right)$. However, this 2.5 -fold decrease in surface area cannot fully account for the 6fold decrease in activity of $2 \mathrm{Pd} / \mathrm{Al}_{2} \mathrm{O}_{3 \text { (IMP) }}$, strongly indicating that other factors of the support (such as acidity) may influence performance.

To further probe how the acidity of the $\mathrm{Al}_{2} \mathrm{O}_{3}$ supports may affect catalytic performance, pyridine DRIFT experiments were 
performed (SI Figure S3), by exposing both $\mathrm{Al}_{2} \mathrm{O}_{3}$ samples to pyridine vapors. ${ }^{40}$ These studies revealed commercial $\gamma-\mathrm{Al}_{2} \mathrm{O}_{3}$ to be much more acidic than $\mathrm{Al}_{2} \mathrm{O}_{3}$ prepared by coprecipitation. To examine whether increased levels of acidity could be responsible for poorer catalytic performance, a complementary sample of $2 \mathrm{Pd} / \mathrm{H}-\beta\left(\mathrm{SiO}_{2} / \mathrm{Al}_{2} \mathrm{O}_{3}=38\right)$ was also prepared by impregnation. Despite exhibiting a very high surface area $\left(498 \mathrm{~m}^{2} \mathrm{~g}^{-1}\right){ }^{41}$ much poorer levels of performance as also observed when this strongly acidic support were employed (Figure 6, Right). Unfortunately, complementary TEM images of $\mathrm{Pd}$ supported on commercial $\gamma-\mathrm{Al}_{2} \mathrm{O}_{3}$ showed that the NPs in this material were highly agglomerated, unlike those found for the coprecipitated catalyst or the IMP@COP catalyst. As such, the poorer levels of performance of $2 \mathrm{Pd} /$ $\mathrm{Al}_{2} \mathrm{O}_{3 \text { (IMP) }}$ cannot be unambiguously attributed to its porosity or acidity. However, it remains clear that the combination of higher surface area and lower acidity makes $\mathrm{Al}_{2} \mathrm{O}_{3(\mathrm{COP})}$ a more suitable support than $\gamma-\mathrm{Al}_{2} \mathrm{O}_{3}$ for the preparation of catalytic materials for the system of study, either by hindering interaction of the catalyst with the acidic substrate, and/or by resulting in the deposition of lower activity $\mathrm{Pd}$ nanoparticles.

Focusing on catalysts involving coprecipitated $\mathrm{Al}_{2} \mathrm{O}_{3}$, further analysis of $2 \mathrm{Pd} / \mathrm{Al}_{2} \mathrm{O}_{3(\mathrm{COP})}$ and $2 \mathrm{Pd} / \mathrm{Al}_{2} \mathrm{O}_{3 \text { (IMP@COP) }}$ by TEM revealed that the coprecipitated sample possessed both a smaller mean particle size and a narrower particle size distribution than the impregnated analogue $(2.85 \pm 0.76 \mathrm{~nm}$ vs $4.51 \pm 2.8 \mathrm{~nm}$, respectively) (Figure 7). Given their
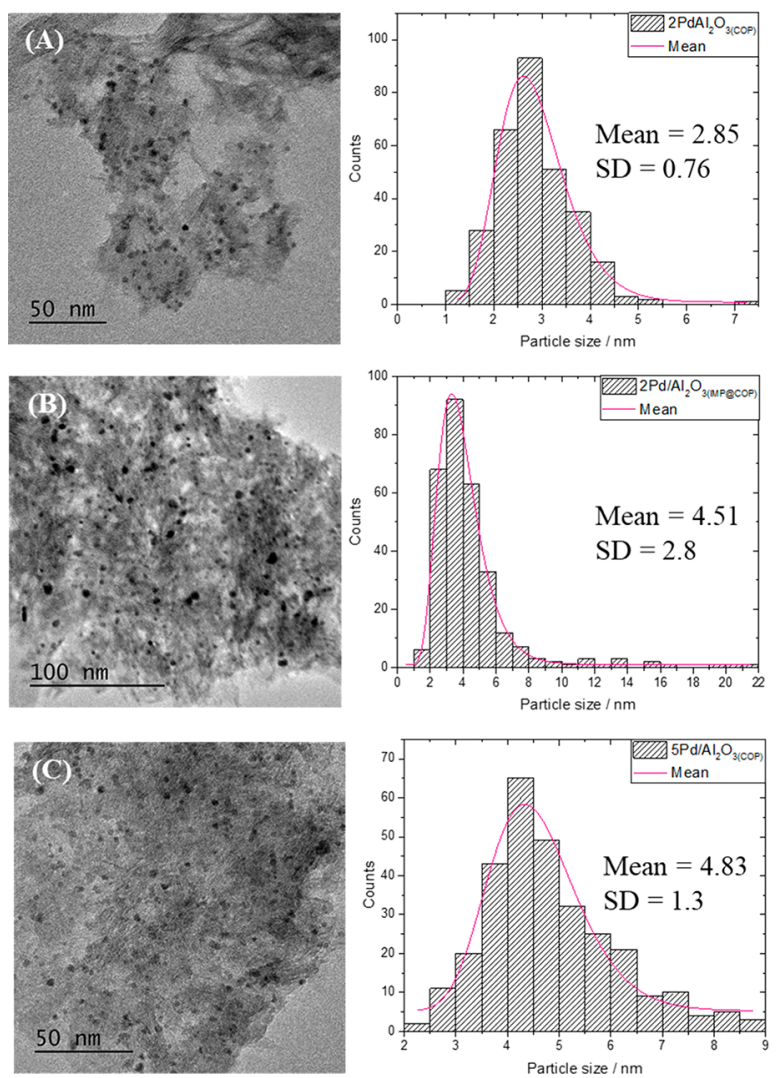

Figure 7. TEM images and accompanying particle size distributions (PSD) for (A) $2 \mathrm{wt} \% \mathrm{Pd} / \mathrm{Al}_{2} \mathrm{O}_{3}$ prepared by coprecipitation, (B) 2 wt $\% \mathrm{Pd} / \mathrm{Al}_{2} \mathrm{O}_{3}$ prepared by impregnation of coprecipitated $\mathrm{Al}_{2} \mathrm{O}_{3}$ and (C) 5 wt $\% \mathrm{Pd} / \mathrm{Al}_{2} \mathrm{O}_{3}$ prepared by coprecipitation. A minimum of 300 particles was counted for each sample. otherwise very similar properties (Table 1), including specific surface area and dominance of metallic Pd (SI Figure S4), the

Table 1. Physical and Textural Properties of Various Pd/ $\mathrm{Al}_{2} \mathrm{O}_{3}$ Catalysts, Prepared by Coprecipitation, Impregnation and Impregnation@coprecipitation

$\begin{array}{lccc}\text { Catalyst } & \begin{array}{c}\text { Pd loading } \\ \%)^{a}\end{array} & \begin{array}{c}\text { Surface area } \\ \left(\mathrm{m}^{2} \mathrm{~g}^{-1}\right)^{b}\end{array} & \begin{array}{c}\text { Particle size } \\ (\mathrm{nm})^{c}\end{array} \\ 2 \mathrm{Pd} / \mathrm{Al}_{2} \mathrm{O}_{3(\mathrm{COP})} & 1.6 & 256 & 2.85 \\ 2 \mathrm{Pd} / & 2.0 & 224 & 4.53 \\ \mathrm{Al}_{2} \mathrm{O}_{3(\mathrm{IMP} @ \mathrm{COP})} & & & \\ 5 \mathrm{Pd} / \mathrm{Al}_{2} \mathrm{O}_{3(\mathrm{COP})} & 4.75 & 242 & 4.83 \\ 2 \mathrm{Pd} / \mathrm{Al}_{2} \mathrm{O}_{3(\mathrm{IMP})} & 2.0 & 85 & \text { n.d. }{ }^{d}\end{array}$

${ }^{a}$ Determined by SEM/EDX analysis. ${ }^{b}$ Calculated from porosimetry analysis by $\mathrm{N}_{2}$ adsorption by the BET method. ${ }^{c}$ Calculated from TEM images. ${ }^{d}$ n.d. $=$ not determined, due to poor contrast in TEM between particle and support.

higher levels of activity exhibited by $2 \mathrm{Pd} / \mathrm{Al}_{2} \mathrm{O}_{3}$ (COP) can tentatively be assigned to its more uniform distribution of smaller Pd nanoparticles. Further indication that catalytic activity has a particle size dependency was provided by investigation of the catalytic performance of $5 \mathrm{Pd} / \mathrm{Al}_{2} \mathrm{O}_{3}$ (COP). This material exhibits a comparable particle size distribution $(4.83 \pm 1.3 \mathrm{~nm})$ to $2 \mathrm{Pd} / \mathrm{Al}_{2} \mathrm{O}_{3 \text { (IMP@COP) }}$, and almost identical catalytic activity when tested at the same substrate-to-metal molar ratio. From an intensification perspective, the activity of a material per mass charge is one of the most critical factors, determining the choice, the design and the size of the eventual catalytic reactor. Therefore, although the intrinsic activity, i.e., turnover frequency, of $5 \mathrm{Pd} / \mathrm{Al}_{2} \mathrm{O}_{3}$ (COP) is $27 \%$ lower than that of $2 \mathrm{Pd} / \mathrm{Al}_{2} \mathrm{O}_{3 \text { (COP) }}\left(2.9 \mathrm{~h}^{-1}\right.$ vs $\left.3.8 \mathrm{~h}^{-1}\right)$, the 2.5 -fold increase in metal loading does substantially boost the productivity of the catalyst, measured on an activity per gram basis, by a factor of $2\left(0.12 \mathrm{~h}^{-1}\right.$ vs $\left.0.06 \mathrm{~h}^{-1}\right)$. Additionally, $5 \mathrm{Pd} / \mathrm{Al}_{2} \mathrm{O}_{3(\mathrm{COP})}$ was shown to be an excellent catalyst to perform the reaction at extended times and achieve high GBL yield maintaining the high selectivity toward GBL (>90\%) even after $24 \mathrm{~h}$ of conversion (SI Figure S5). Accordingly, for future intensification studies, the higher loaded catalyst $\left(5 \mathrm{Pd} / \mathrm{Al}_{2} \mathrm{O}_{3(\mathrm{COP})}\right)$ likely presents the optimal compromise between intrinsic activity and catalyst productivity. To further probe this, an extended time online reaction for $5 \mathrm{Pd} / \mathrm{Al}_{2} \mathrm{O}_{3(\mathrm{COP})}$ was also performed at higher temperature (Figure 8, Left). As can be seen, in only 4 h, a GBL yield of $64 \%$ was obtained during this reaction at 200 ${ }^{\circ} \mathrm{C}$, representing a productivity of $0.33 \mathrm{~g}(\mathrm{GBL}) \mathrm{g}^{-1}$ (catalyst) $\mathrm{h}^{-1}$. Further improvement in terms of GBL productivity was also obtained at higher initial SA concentration, i.e., at higher substrate metal ratio. As shown in Figure 8, Right, reactions performed with SA solutions of $0.6 \mathrm{M}$ (3 times more concentrated), but with the same mass of catalyst (resulting in a Pd content of $0.67 \mathrm{~mol} \%$, as opposed to $2 \mathrm{~mol} \%$ ) resulted in an increased GBL productivity of $0.39 \mathrm{~g}$ (GBL) $\mathrm{g}^{-1}$ (catalyst) $\mathrm{h}^{-1}$ being obtained (SI Table S1, Entry 12). In this case, high selectivity toward GBL could be maintained over extended periods of time and at elevated conversion, as demonstrated by running a reaction for $16 \mathrm{~h}$ at the higher concentration of SA (SI Figure S6).

Alongside high levels of catalytic activity and selectivity, heterogeneous catalysts must also possess high levels of stability, and an ability to operate for more than one reaction period. $^{42}$ Unfortunately, several factors make the design of reusable catalysts for biomass conversion a major challenge, 

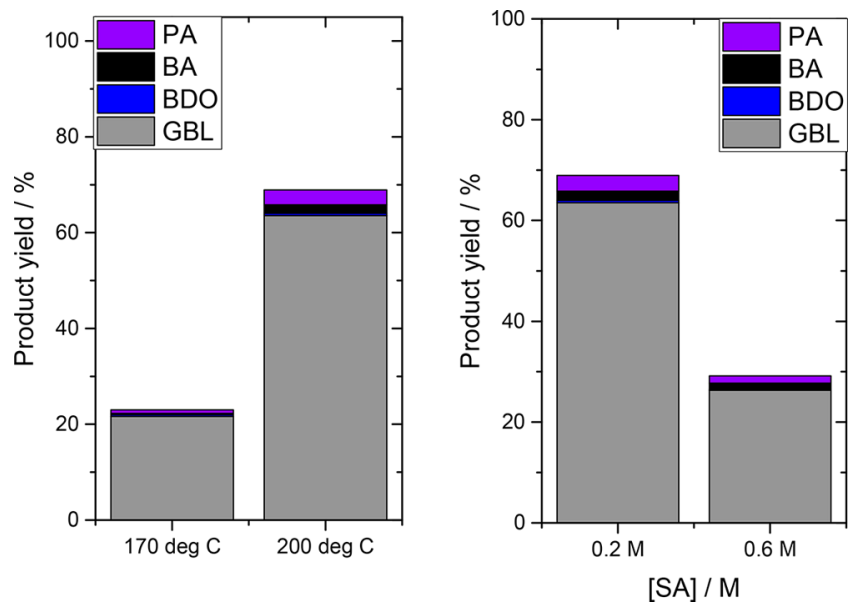

Figure 8. Performance of 5 wt $\% \mathrm{Pd} / \mathrm{Al}_{2} \mathrm{O}_{3}$ catalyst prepared by coprecipitation (COP) after $4 \mathrm{~h}$ of reaction (Left) at 170 and $200^{\circ} \mathrm{C}$, using $0.2 \mathrm{M}$ of SA, 30 bar of $\mathrm{H}_{2}$ and $2 \mathrm{~mol} \% \mathrm{Pd}$ with respect to SA. (Right) Catalytic performance of $5 \mathrm{wt} \% \mathrm{Pd} / \mathrm{Al}_{2} \mathrm{O}_{3} \mathrm{COP}$ at $200{ }^{\circ} \mathrm{C}$, using 0.2 and $0.6 \mathrm{M}$. In both reactions, identical mass of catalyst was employed, resulting in Pd contents of 2 and $0.67 \mathrm{~mol} \%$ with respect to $\mathrm{SA}$, respectively.

including the harsh reaction conditions typically required (presence of solvent at high temperature and pressure), and the chelating nature of the oxygenated substrates, such as sugars and acids, which are known to cause leaching and agglomeration of various metallic nanoparticles. ${ }^{43,44}$ Thus, to gain a preliminary understanding of the reusability properties of $2 \mathrm{Pd} / \mathrm{Al}_{2} \mathrm{O}_{3(\mathrm{CO})}$, recyclability experiments were performed. To do so, the catalyst was filtered out of the reactor following one kinetic experiment, and subsequently reused in a second and third catalytic experiment. To achieve the most accurate level of insight, and to probe intrinsic reusability of the catalyst, no intermediate treatments were performed on the material, i.e., the catalyst was simply filtered from solution, dried at room temperature, and then placed back in the reactor. Furthermore, comparison of the initial activity of the material was done, to mitigate errors associated with evaluating reusability at high levels of conversion. ${ }^{37}$ As can be seen (Figure 9), excellent reusability is observed for $2 \mathrm{Pd} /$

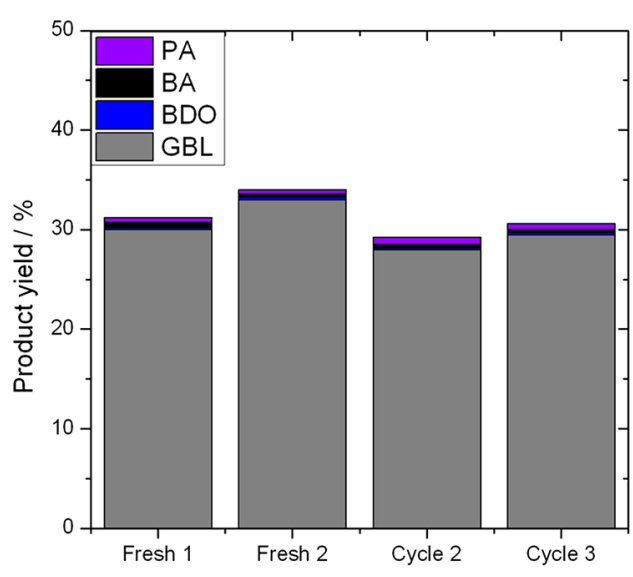

Figure 9. Reusability studies of $2 \mathrm{Pd} / \mathrm{Al}_{2} \mathrm{O}_{3 \text { (COP) }}$ for the hydrogenation of succinic acid. No intermediate regeneration treatments were performed between cycles. Reaction conditions $170{ }^{\circ} \mathrm{C}, 2 \mathrm{~mol} \% \mathrm{Pd}$ relative to $\mathrm{SA}, 2 \mathrm{~h}$ of reaction time, $30 \mathrm{bar}_{2}$.
$\mathrm{Al}_{2} \mathrm{O}_{3 \text { (COP) }}$, with no loss of activity being observed over three kinetic cycles. The high levels of stability exhibited by the catalyst is a promising discovery for future intensification studies. $^{42}$

Preliminary Identification of Reaction Network. At the optimized reaction conditions, it is clear that the hydrogenation of SA can be achieved under the influence of various $\mathrm{Al}_{2} \mathrm{O}_{3}$-supported metal nanoparticles. However, it is clear that the choice of metallic center dramatically impacts the overall selectivity of the reaction. Whereas $\mathrm{Pd} / \mathrm{Al}_{2} \mathrm{O}_{3(\mathrm{COP})}$ is almost exclusively selective to $\mathrm{GBL}, 5 \mathrm{Ru} / \mathrm{Al}_{2} \mathrm{O}_{3}$ (COM) exhibits comparable levels of selectivity to GBL and PA. The presence of multiple products in this case indicates that more than one reaction pathway can occur during the reaction. Accordingly, to gain a greater understanding of the reaction system, in addition to gaining some insight into the more selective mechanism of $\mathrm{Pd}$ during SA valorization, product stability studies were performed. These were performed by substituting the SA substrate for other feasible products of the reaction network, including PA, BA, GBL and BDO, and testing their reactivity as substrates under similar reaction conditions. For these studies, $5 \mathrm{Ru} / \mathrm{Al}_{2} \mathrm{O}_{3(\mathrm{COM})}$ was employed, as this catalyst exhibited the highest degree of consecutive and/or parallel reaction pathways. As can be seen (Table 2), low levels of

Table 2. Product Stability Studies Performed under Typical Reaction Conditions ${ }^{a}$

\begin{tabular}{lcccc} 
& \multicolumn{5}{c}{ Product yield (\%) } \\
\cline { 2 - 5 } \multicolumn{1}{c}{ System } & GBL & BDO & PA & BA \\
GBL, $\mathrm{H}_{2}$, catalyst & - & 1.8 & 3.0 & 0.9 \\
BDO, $\mathrm{H}_{2}$, catalyst & 1.3 & - & 0 & 0 \\
PA, $\mathrm{H}_{2}$, catalyst & 0.2 & 0.5 & - & 0 \\
BA, $\mathrm{H}_{2}$, catalyst & 0 & 0.4 & 0 & - \\
GBL, $\mathrm{H}_{2}$, no catalyst & - & 0 & 0 & 0 \\
GBL, $\mathrm{N}_{2}$, catalyst & - & 1.0 & 0 & 0
\end{tabular}

${ }^{a}$ Reaction conditions: $15 \mathrm{~mL}$ of $0.2 \mathrm{M}$ of substrate in 1,4-dioxane, 15 bar of $\mathrm{H}_{2}, 1 \mathrm{~mol} \%$ of Ru with respect to the substrate tested at 170 ${ }^{\circ} \mathrm{C}$ for a period of $6 \mathrm{~h}$.

reactivity are observed for all these substrates under comparable reaction conditions to SA, with only GBL demonstrating more than trace levels of conversion to any other product. The low levels of reactivity observed in each of these cases indicates that there are no major consecutive reactions present, and that the main products observed during SA conversion with $5 \mathrm{Ru} / \mathrm{Al}_{2} \mathrm{O}_{3(\mathrm{COM})}$ (GBL and $\mathrm{PA}$ ) occur from two separate pathways, allowing disclosure of the full reaction network (Figure 10). This is further supported by the observation that the selectivity obtained to GBL during SA hydrogenation with $5 \mathrm{Ru} / \mathrm{Al}_{2} \mathrm{O}_{3(\mathrm{COM})}$ is almost invariant at all levels of product yield (Figure 3, right). From this, it can be ruled out selectivity to GBL is lost with $5 \mathrm{Ru} / \mathrm{Al}_{2} \mathrm{O}_{3}$ (COM) due to its ability to convert GBL to consecutive products. Rather, the presence of $\mathrm{Ru}$ opens up additional reaction pathways that are not observed over $2 \mathrm{Pd} / \mathrm{Al}_{2} \mathrm{O}_{3(\mathrm{COM})}$.

To gain further insight as to the more selective nature of $\mathrm{Pd} /$ $\mathrm{Al}_{2} \mathrm{O}_{3}$ vs $\mathrm{Ru} / \mathrm{Al}_{2} \mathrm{O}_{3}$, preliminary spectroscopic experiments focused upon the activation of carboxylic acids by these materials were performed by diffuse reflectance fourier transform infrared (DRIFT) spectroscopy. Unfortunately, the poor volatility of SA prohibits its study by this technique. To overcome this, and to focus exclusively upon the binding of the 


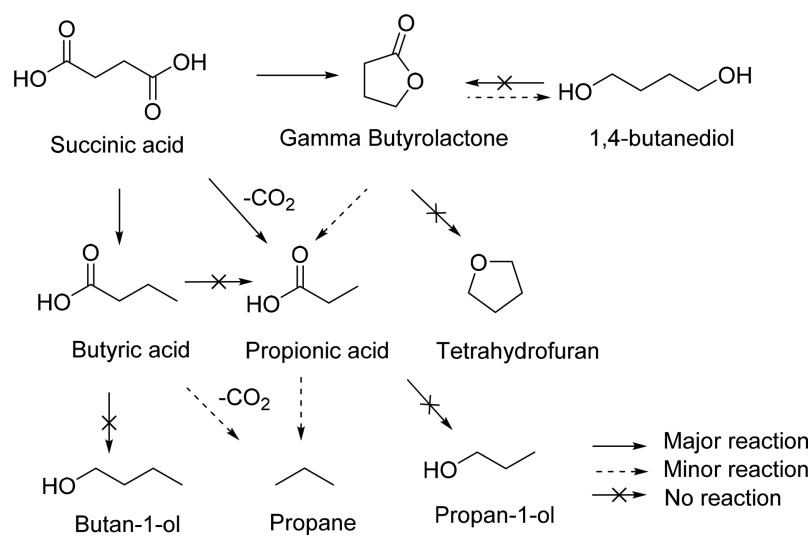

Figure 10. Full reaction network of SA hydrogenation at the mild reaction conditions.

acidic functionality, DRIFTS measurements were thus performed on pivalic acid, a tertiary carboxylic acid that cannot undergo lactonization. After dosing with pivalic acid, all three samples exhibit vibrational patterns consistent with physisorbed pivalic acid (SI Figure S7). ${ }^{45}$ However, following evacuation at $100{ }^{\circ} \mathrm{C}$ and removal of physisorbed pivalic acid, obvious differences between both active catalysts (5Ru/ $\left.\mathrm{Al}_{2} \mathrm{O}_{3}(\mathrm{COM}), 5 \mathrm{Pd} / \mathrm{Al}_{2} \mathrm{O}_{3(\mathrm{COM})}\right)$ and the inactive support material alone are observed (Figure 11, SI Figure S8), and stretches related to the deprotonated pivalate are also observed. ${ }^{45}$ Because no conversion occurs in the absence of hydrogen (Table S2) and the probe molecule pivalic acid cannot undergo lactonization, it can be discounted that these changes are due to the formation of a reaction product.

Figure 11 presents the DRIFT spectra of $5 \mathrm{Ru} / \mathrm{Al}_{2} \mathrm{O}_{3(\mathrm{COM})}$, $5 \mathrm{Pd} / \mathrm{Al}_{2} \mathrm{O}_{3(\mathrm{COM})}$ and $\mathrm{Al}_{2} \mathrm{O}_{3}$, following dosing with pivalic acid and subsequent heat treatment at $100{ }^{\circ} \mathrm{C}$ (Left) and $300{ }^{\circ} \mathrm{C}$ (Right). When compared to the inactive support material itself, two distinct vibrations in both metal-doped catalysts can be distinguished at approximately 1650 and $\pm 1415 \mathrm{~cm}^{-1}$. These can readily be attributed to the asymmetric $\left(v_{\mathrm{as}}\right)$ and symmetric $\left(v_{\text {sym }}\right)$ stretches of the metal-coordinated carboxylate, respectively. ${ }^{46}$ Interestingly, the precise wavenumbers of these stretches differs according to the choice of metal, with the difference $(\Delta)$ in energy between $v_{\text {as }}$ and $v_{\text {sym }}\left(\Delta=v_{\text {as }}-\right.$ $v_{\text {sym }}$ ) increasing from $214 \mathrm{~cm}^{-1}$ for $5 \mathrm{Ru} / \mathrm{Al}_{2} \mathrm{O}_{3(\mathrm{COM})}$ to 264 $\mathrm{cm}^{-1}$ for $5 \mathrm{Pd} / \mathrm{Al}_{2} \mathrm{O}_{3(\mathrm{COM})}$. The value of $\Delta$ relates to the type of binding mode in metal-acetate species, with increasing values of $\Delta$ indicating greater inequivalence between the $\mathrm{C}-\mathrm{O}$ bonds, and a shift toward more unidentate coordination. ${ }^{45}$ As such, these studies indicate that carboxylic acids, such as pivalic acid and $\mathrm{SA}$, bind differently to $5 \mathrm{Pd} / \mathrm{Al}_{2} \mathrm{O}_{3}(\mathrm{COM})$ and $5 \mathrm{Ru} /$ $\mathrm{Al}_{2} \mathrm{O}_{3}$ (COM). As can be seen, this difference in coordination is still evident even at higher desorption temperatures (Figure 11, Right and Figure S8).

Unfortunately, the poor volatility of SA (vide supra) prohibits its detailed vibrational study by these methods. Hence, to further explore how SA coordinates to both $5 \mathrm{Pd} /$

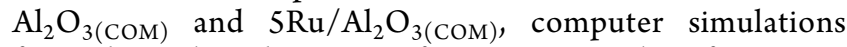
focused on the adsorption of SA onto metal surfaces were performed (Figure 12). The most stable surfaces for $\mathrm{Ru}$ and Pd, i.e., (0001) and (111) respectively, were employed. These calculations reveal that SA adsorbs with a similar strength on both metal surfaces, with values of 1.1 and $0.9 \mathrm{eV}$ determined for $\mathrm{Ru}$ and $\mathrm{Pd}$, respectively. Likewise, free SA binds to both surfaces through the carboxylic groups, with negligible levels of electron transfer occurring $(<0.1 \mathrm{eV})$ in both cases. However, although calculations indicate SA binds through the same functional group on both surfaces (Figure 12), the precise geometry of this coordination and the type of binding differs on both metals. As can be seen (Figure 12, top right), whereas the coordination of SA over $\mathrm{Ru}$ appears to be bidentate (the deprotonated carboxylate exhibiting two $\mathrm{C}-\mathrm{O}$ bonds of 0.127 and $0.129 \mathrm{~nm}$ ), SA coordination over Pd is more unidentate, with two inequivalent $\mathrm{C}-\mathrm{O}$ bonds of 0.124 and $0.132 \mathrm{~nm}$ being observed. This observation is in excellent agreement to the DRIFTS studies of pivalic acid, which also indicated greater unidentate coordination over Pd. To further probe the relevance of these observations with respect to the DRIFTS studies of pivalic acid coordination, the vibrational spectrum of succinic acid coordinated on $\mathrm{Ru}(0001)$ and $\mathrm{Pd}$ (111) was generated (Figure S9). Two major vibrations at approximately $1600\left(v_{\text {as }}\right)$ and $1384 \mathrm{~cm}^{-1}\left(v_{\text {sym }}\right)$ are predicted following adsorption of SA onto $\mathrm{Pd}$ and $\mathrm{Ru}$, in excellent agreement to the DRIFTS studies of pivalic acid. In further agreement to the vibrational spectra, the $\Delta$ value observed in the predicted
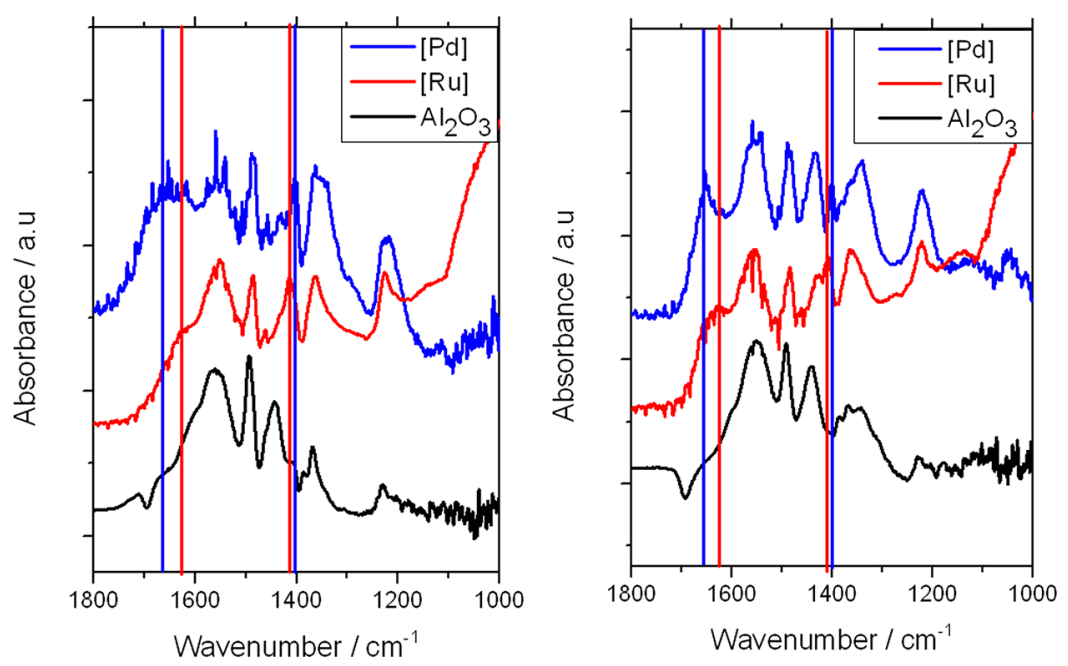

Figure 11. DRIFTS spectra of $5 \mathrm{Pd} / \mathrm{Al}_{2} \mathrm{O}_{3(\mathrm{COM})}([\mathrm{Pd}]), 5 \mathrm{Ru} / \mathrm{Al}_{2} \mathrm{O}_{3(\mathrm{COM})}([\mathrm{Ru}])$ and $\mathrm{Al}_{2} \mathrm{O}_{3}$ itself following dosing with pivalic acid at room temperature and evacuation at (Left) $100{ }^{\circ} \mathrm{C}$ and (Right) $300{ }^{\circ} \mathrm{C}$. 


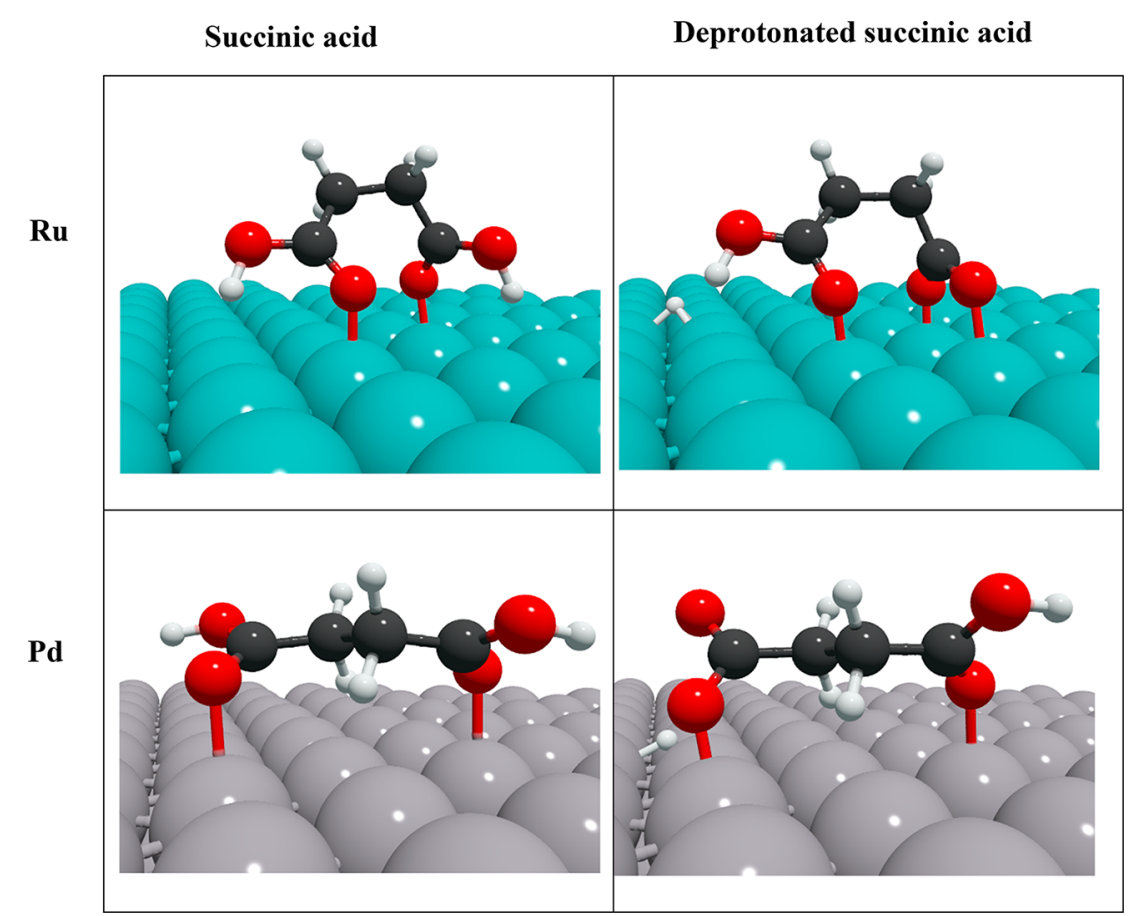

Figure 12. Schematic representation of succinic acid (Left) adsorbed on $\operatorname{Ru}(0001)$ (Top) and $\operatorname{Pd}(111)$ (Bottom) and representation of deprotonated molecule (Right) adsorbed onto $\mathrm{Ru}(0001)$ (Top) and $\operatorname{Pd}(111)$ (Bottom).

spectra is also greater for Pd than for $\mathrm{Ru}$, at 251 and $208 \mathrm{~cm}^{-1}$, respectively. Although detailed reaction coordinate analysis is required before definitive mechanistic hypotheses can be made, these initial vibrational and computational studies clearly indicate that the choice of metal impacts the coordination and hence, the geometry, of SA at the active site at reaction conditions, and likely accounts for the improved selectivity of $\mathrm{Pd}$ versus $\mathrm{Ru}$ during SA hydrogenation. Such computational studies, focused upon generating such a detailed molecular level mechanism, represent the focus of our ongoing work.

\section{CONCLUSIONS}

In this paper, we show that succinic acid, a $\mathrm{C} 4$ compound increasingly being produced on a several kiloton scale by the microbial fermentation of sugar, can be selectively converted into a variety of important chemicals. Optimal performance in terms of activity, selectivity and reusability is observed for $2 \mathrm{wt}$ $\% \mathrm{Pd}$ supported on $\mathrm{Al}_{2} \mathrm{O}_{3}$, which converts succinic acid selectivity to $\gamma$-butyrolactone at levels above $95 \%$ To the best of our knowledge, the reaction conditions optimized in this study represent the mildest set of conditions for succinic acid valorization to date, being $100{ }^{\circ} \mathrm{C}$ lower in temperature, and $<6$ bar lower in pressure than previously reported. Complementary spectroscopic and microscopic studies reveal that optimal activity depends on the choice of support and the size of the supported Pd nanoparticles. The increased lactone selectivity observed with Pd compared to other metallic centers, e.g., $\mathrm{Ru}$, is tentatively attributed by in situ DRIFTS spectroscopy to the greater ability of Pd to activate the carboxylic acid moiety of the substrate, hence facilitating lactonization of the molecule during catalysis.

\section{EXPERIMENTAL SECTION}

Catalyst Synthesis. Preparation by Coprecipitation Method (COP). The required amount of metal chloride precursor solution (typically $5 \mathrm{mg} \mathrm{mL}^{-1}$ of potassium tetrachloropalladate (II), 98\%,
Sigma-Aldrich) to prepare $1 \mathrm{~g}$ of $2 \mathrm{wt} \%$ loading catalyst, was added into a beaker with deionized water $(50 \mathrm{~mL})$ under continuous stirring $\left(700 \mathrm{rpm}\right.$ ) at $25{ }^{\circ} \mathrm{C}$. The support precursor (aluminum nitrate nonahydrate, $99.9 \%$, Sigma-Aldrich) was then added, and the $\mathrm{pH}$ adjusted to 9 through the gradual addition of solid $\mathrm{Na}_{2} \mathrm{CO}_{3}$. The suspension was then equilibrated under stirring for $1 \mathrm{~h}$ and the resultant slurry filtered and washed extensively with deionized water (3 L per g of catalyst). The solid was then oven-dried at $100{ }^{\circ} \mathrm{C}$ for 16 $\mathrm{h}$ before being reduced at $200{ }^{\circ} \mathrm{C}$ for $3 \mathrm{~h}$ under $5 \% \mathrm{H}_{2} / \mathrm{Ar}$ flow (100 $\left.\mathrm{mL} \mathrm{min}^{-1}\right)$. When a catalyst with different Pd loading was prepared, required amounts of metal and support precursor were adjusted appropriately. When catalysts with different metals were prepared, the same method was applied using the following precursors: nickel(II) chloride hexahydrate (Alfa Aesar), copper(II) chloride dihydrate (Alfa Aesar), ruthenium(III) chloride hydrate (Sigma-Aldrich) and iridium(IV) chloride (Alfa Aesar).

Preparation by Wet Impregnation Method (IMP). The required amount of metal chloride precursor solution to prepare $1 \mathrm{~g}$ of catalyst was added into a $50 \mathrm{~mL}$ round-bottomed flask with a magnetic stirrer $(700 \mathrm{rpm})$ at $25{ }^{\circ} \mathrm{C}$. Deionized water was added to adjust the total volume $16 \mathrm{~mL}$ before the flask was immersed in an oil bath and temperature was increased to $60{ }^{\circ} \mathrm{C}$. Once the temperature was reached, the support was gradually added, and the resultant slurry stirred for $15 \mathrm{~min}$. The oil bath temperature was increased to $95{ }^{\circ} \mathrm{C}$ and stirred until all the water had been evaporated, leaving a dry solid. The solid thus obtained was then reduced at $200{ }^{\circ} \mathrm{C}$ for $3 \mathrm{~h}$ under $5 \%$

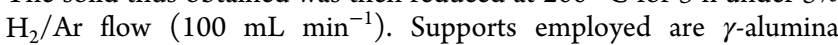
(Sigma-Aldrich), $\beta$ zeolite (Zeolyst, $\mathrm{NH}_{4}$-form, $\mathrm{SiO}_{2} / \mathrm{Al}_{2} \mathrm{O}_{3}=38$ ) converted into proton form $(\mathrm{H}-\beta)$ and magnesium oxide (MgO light, $\mathrm{BDH})$.

Catalyst Characterization. X-ray Diffraction (XRD). A Panalytical X'PertPRO X-ray diffractometer was employed for powder $\mathrm{XRD}$ analysis with a $\mathrm{Cu} \mathrm{K} \alpha$ radiation source $(40 \mathrm{kV}$ and $30 \mathrm{~mA})$. Diffraction patterns were recorded between 5 and $802 \theta$.

Porosimetry Analysis. Porosimetry measurements were performed on a Quantachrome Autosorb, and samples were degassed prior to measure $\left(120^{\circ} \mathrm{C}, 6 \mathrm{~h}\right) . \mathrm{N}_{2}$ adsorption isotherms were obtained at 77 $\mathrm{K}$ and surface areas were calculated using the Brunauer-EmmettTeller (BET) method based on adsorption data in the partial pressure $\left(P / P_{0}\right)$ range $0.05-0.35$. 
Microscopy Analysis. A transmission electron microscopy (TEM) JEM-2100 LaB6 instrument operating at $300 \mathrm{kV}$ was employed to determine how different synthesis methods affected the average particle size and particle distribution on the surface of the catalysts. The catalyst powder was dispersed in ethanol using ultrasonication and $40 \mu \mathrm{L}$ of the suspension was dropped on to a holey carbon film supported by a 300 mesh copper TEM grid before the solvent was evaporated prior the analysis. Additionally, a scanning electron microscopy (SEM) Hitachi TM3030Plus instrument equipped with Quantax70 energy-dispersive X-ray spectroscopy (EDX) equipment was used at $15 \mathrm{kV}$ and at EDX observation conditions to analyze the elemental composition and uniform distribution throughout all the sample.

X-ray Photoelectron Spectroscopy (XPS). XPS spectra were recorded on a Kratos Axis Ultra DLD spectrometer using a monochromatic $\mathrm{Al} \mathrm{K} \alpha \mathrm{X}$-ray source. X-ray source (75-150 W) and analyzer pass energies of $160 \mathrm{eV}$ (for survey scans) or $40 \mathrm{eV}$ (for detailed scans).

Diffuse Reflectance Fourier Transform Infrared (DRIFT) Spectroscopy. DRIFTS analysis was performed with a Bruker Tensor II equipped with a Harrick praying mantis DRIFT cell. For the pyridine DRIFTS experiments, samples were degassed for $2 \mathrm{~h}$ under $\mathrm{N}_{2}$ flow $\left(20 \mathrm{~mL} \mathrm{~min}{ }^{-1}\right)$ at $150{ }^{\circ} \mathrm{C}$ and cooled at room temperature prior dosing the pyridine (kept at $30{ }^{\circ} \mathrm{C}$ ) through the $\mathrm{N}_{2}$ flow $(40 \mathrm{~mL}$ $\mathrm{min}^{-1}$ ) for $30 \mathrm{~min}$. Then the system was heated up at increasing desorption temperatures, up to $500{ }^{\circ} \mathrm{C}$ and constantly monitored by IR spectrometer. For pivalic acid DRIFTS experiments, samples were degassed following the same procedure as followed for pyridine, prior to dosing pivalic acid sublimated at $130{ }^{\circ} \mathrm{C}$ (boiling point of $165^{\circ} \mathrm{C}$ ) through the $\mathrm{N}_{2}$ flow $\left(40 \mathrm{~mL} \mathrm{~min}^{-1}\right)$ for $60 \mathrm{~min}$. Subsequently, and in a manner analogous to the pyridine experiments, the system was gradually heated up to evaluate the probe molecule desorption.

Kinetic Evaluation and Analytical Methods. Liquid-Phase Hydrogenation of Succinic Acid (SA). Catalytic evaluation of SA hydrogenation to GBL was carried out using a Parr Compact Mini Bench Top Reactor $5500(100 \mathrm{~mL})$ with a Parr 4848 Reactor controller. In a typical reaction, $15 \mathrm{~mL}$ of $0.2 \mathrm{M}$ SA solution in 1,4dioxane (succinic acid, 99.9\%, Sigma-Aldrich and 1,4-dioxane, 99\%, Alfa Aesar) and reduced catalyst (amount required depending on metal loading and mol \% substrate ratio used, usually 2 wt \% of Pd and $2 \mathrm{~mol} \% \mathrm{Pd}$ with respect SA) were charged into a reactor vessel. The reactor was purged three times and then it was pressurized up to 30 bar with $\mathrm{H}_{2}$. The reactant solution was heated to the reaction temperature $\left(170{ }^{\circ} \mathrm{C}\right)$, and the reaction was initiated by stirring the vessel at $1500 \mathrm{rpm}$. The reaction was typically run under continuous stirring for a $4 \mathrm{~h}$ period. Reaction products analysis required the use of HPLC and GC analytical techniques. SA quantification was carried out by an Agilent 1220 HPLC equipped with a variable wavelength detector (VWD) and a Metacarb $87 \mathrm{H}$ Column $250 \times 4.6 \mathrm{~mm}$ at 60 ${ }^{\circ} \mathrm{C}$, with $0.4 \mathrm{~mL} \min ^{-1}$ of $0.1 \mathrm{wt} \% \mathrm{H}_{3} \mathrm{PO}_{4}$ aqueous solution as eluent, against citric acid (CA) $0.01 \mathrm{M}$ as external standard. $\gamma$-Butyrolactone (GBL), 1,4-butanediol (BDO), butyric acid (BA) and propionic acid (PA) were quantified by an Agilent $7890 \mathrm{~B}$ gas chromatograph equipped with a FID detector and a $25 \mathrm{~m}$ CP-Wax 52 CB column, against $0.01 \mathrm{M}$ of biphenyl as external standard. Additionally, gas products were analyzed using a Varian 450-GC gas chromatograph equipped with a flame ionization detector (FID) with a methanizer.

Reusability Studies. Catalyst reusability was carried out after simple filtration of the catalyst. Between measurements, the catalyst was dried overnight at room temperature. Reaction conditions and analytics were performed following the same procedure described above.

Computational Experiments. Periodic plane-wave DFT calculations were performed using the Vienna ab initio simulation package (VASP), ${ }^{47-50}$ the Perdew-Burke-Ernzerhof functional ${ }^{51}$ and a kinetic energy of $550 \mathrm{eV}$ to expand the plane-waves of the KohnSham valence states. The inner electrons were represented by the projector-augmented wave (PAW) pseudopotentials considering also nonspherical contributions from the gradient corrections. ${ }^{52}$ All the calculations include the long-range dispersion correction approach by
Grimme. ${ }^{53}$ The optimization thresholds were $10^{-5} \mathrm{eV}$ and $0.01 \mathrm{eV} / \AA$ for electronic and ionic relaxation, respectively. The Brillouin zone was sampled by $\Gamma$-centered $k$-point mesh generated through a Monkhorst-Pack grid of $5 \times 5 \times 1$ k-points, which ensures the electronic and ionic convergence. In order to improve the convergence of the Brillouin-zone integrations, the partial occupancies were determined using the first-order Methfessel-Paxton method corrections smearing with a set width for all calculations of $0.2 \mathrm{eV}$. The metal surfaces are simulated by a $\mathrm{p}(4 \times 4)$ slab model containing five atomic layers where the two uppermost layers were relaxed without symmetry restrictions and the bottom ones were frozen at the bulk lattice parameter. We added a vacuum width of $15 \AA$ between periodic slabs, big enough to avoid the interaction between periodic images. Isolated molecules were placed in the center of a $15 \times 16 \times$ $17 \AA ̊$ cell and optimized with the same criteria.

\section{ASSOCIATED CONTENT}

\section{Supporting Information}

The Supporting Information is available free of charge on the ACS Publications website at DOI: 10.1021/acssuschemeng.8b03346.

Additional spectroscopic and kinetic information (PDF)

\section{AUTHOR INFORMATION}

\section{Corresponding Author}

*C. Hammond. E-mail: hammondc4@cardiff.ac.uk. Tel: +44 (0) 2920876002 .

ORCID

Antoine Buchard: 0000-0003-3417-5194

Ceri Hammond: 0000-0002-9168-7674

\section{Notes}

The authors declare no competing financial interest.

\section{ACKNOWLEDGMENTS}

C.H. gratefully appreciates the support of The Royal Society, for provision of a University Research Fellowship (UF140207). A.B. gratefully appreciates the support of The Royal Society, for provision of a University Research Fellowship (UF160021). C.H., K.Y. and A.B. are grateful to the Catalysis CDT for provision of $\mathrm{PhD}$ studentship funding (EP/L016443/1).

\section{REFERENCES}

(1) Facing the Hard Truths about Energy; U.S. National Petroleum Council: Washington DC, 2007.

(2) Zhu, J.; Zhang, X.; Pan, X. Sustainable Production of Fuels, Chemicals, and Fibres from Forest Biomass, ACS Symposium Series 2011, Vol. 1067, 89,.

(3) Plastic-The Facts, Plastics Europe, www.plasticseurope.org, 2016.

(4) Delhomme, C.; Weuster-Botz, D.; Kühn, F. E. Succinic acid from renewable resources as a $\mathrm{C} 4$ building-block chemical-a review of the catalytic possibilities in aqueous media. Green Chem. 2009, 11, 13-26.

(5) Luterbacher, J. S.; Martin Alonso, D.; Dumesic, J. A. Targeted chemical upgrading of lignocellulosic biomass to platform molecules. Green Chem. 2014, 16, 4816-4838.

(6) Vilela, C. F.; Sousa, A. F.; Fonseca, A. C.; Serra, A. C.; Coelho, J. F. J.; Freire, C. S. R.; Silvestre, A. J. D. The quest for sustainable polyesters - insights into the future. Polym. Chem. 2014, 5, 31193141 .

(7) van Haveren, J.; Scott, E. L.; Sanders, J. Bulk chemicals from biomass. Biofuels, Bioprod. Biorefin. 2008, 2, 41-57.

(8) Gallezot, P. Conversion of biomass to selected chemical products. Chem. Soc. Rev. 2012, 41, 1538-1558. 
(9) Delidovich, I.; Leonhard, K.; Palkovits, R. Cellulose and Hemicellulose Valorisation: An Integrated Challenge of Catalysis and Reaction Engineering. Energy Environ. Sci. 2014, 7, 2803-2830.

(10) Corma, A.; Iborra, S.; Velty, A. Chemical routes for the transformation of biomass into chemicals. Chem. Rev. 2007, 107, $2411-2502$.

(11) Kunkes, E. L.; Simonetti, D. A.; West, R. M.; Serrano-Ruiz, J. C.; Gärtner, C. A.; Dumesic, J. Catalytic conversion of biomass to monofunctional hydrocarbons and targeted liquid-fuel classes. Science 2008, 322, 417-421.

(12) Shylesh, S.; Gokhale, A. A.; Ho, C. R.; Bell, A. T. Novel Strategies for the Production of Fuels, Lubricants, and Chemicals from Biomass. Acc. Chem. Res. 2017, 50, 2589-2597.

(13) Hill, J.; Nelson, E.; Tilman, D.; Polasky, S.; Tiffany, D. Environmental, economic, and energetic costs and benefits of biodiesel and ethanol biofuels. Proc. Natl. Acad. Sci. U. S. A. 2006, 103, 11206-11210.

(14) Ragauskas, A. J.; Williams, C. K.; Davison, B. H.; Britovsek, G.; Cairney, J.; Eckert, C. A.; Frederick, W. J., Jr; Hallett, J. P.; Leak, D. J.; Liotta, C. L.; Mielenz, J. R.; Murphy, R.; Templer, R.; Tschaplinski, T. The Path Forward for Biofuels and Biomaterials. Science 2006, 311, 484-489.

(15) Biochemical Opportunities in the United Kingdom; NNFCC project 08-008; The National Non-Food Crops Centre, 2008.

(16) Werpy, T.; Petersen, G. Top Value Added Chemicals from Biomass Volume I - Results of Screening for Potential Candidates from Sugars and Synthesis Gas; Pacific Northwest National Laboratory and the National Renewable Energy Laboratory, 2004.

(17) Tsao, G. T.; Cao, N. J.; Du, J.; Gong, C. S. Production of Multifunctional Organic Acids from Renewable Resources. Adv. Biochem. Eng. Biotechnol. 1999, 65, 243-80.

(18) Song, H.; Lee, S. Y. Production of succinic acid by bacterial fermentation. Enzyme Microb. Technol. 2006, 39, 352-361.

(19) Cao, Y.; Zhang, R.; Sun, C.; Cheng, T.; Liu, Y.; Xian, M. Fermentative Succinate Production: An Emerging Technology to Replace the Traditional Petrochemical Processes. BioMed Res. Int. 2013, 2013, No. 723412.

(20) Varadarajan, S.; Miller, D. J. Catalytic Upgrading of Fermentation-Derived Organic Acids. Biotechnol. Prog. 1999, 15 , 845-854.

(21) Erickson, B.; Nelson, J. E.; Winters, P. Perspective on opportunities in industrial biotechnology in renewable chemicals. Biotechnol. J. 2012, 7, 176-185.

(22) Bechthold, I.; Bretz, K.; Kabasci, S.; Kopitzky, R.; Springer, A. Succinic Acid: A New Platform Chemical for Biobased Polymers from Renewable Resources. Chem. Eng. Technol. 2008, 31, 647-654.

(23) Pham Minh, D.; Besson, M.; Pinel, C.; Fuertes, P.; Petitjean, C. Aqueous-Phase Hydrogenation of Biomass-Based Succinic Acid to 1,4-Butanediol Over Supported Bimetallic Catalysts. Top. Catal. 2010, 53, 1270-1273.

(24) Hong, U. G.; Hwang, S.; Seo, J. G.; Yi, J.; Song, I. K. Hydrogenation of Succinic Acid to $\gamma$-Butyrolactone over Palladium Catalyst Supported on Mesoporous Alumina Xerogel. Catal. Lett. 2010, 138, 28-33.

(25) Hong, U. G.; Lee, J.; Hwang, S.; Song, I. K. Hydrogenation of succinic acid to $\gamma$-butyrolactone (GBL) over palladium-alumina composite catalyst prepared by single-step sol-gel method. Catal. Lett. 2011, 141, 332-338.

(26) You, C.; Zhang, C.; Chen, L.; Qi, Z. Highly dispersed palladium nanoclusters incorporated in amino-functionalized silica spheres for the selective hydrogenation of succinic acid to $\gamma$-butyrolactone. Appl. Organomet. Chem. 2015, 29, 653-660.

(27) Di, X.; Shao, Z.; Li, C.; Li, W.; Liang, C. Hydrogenation of succinic acid over supported rhenium catalysts prepared by microwave assisted thermolytic method. Catal. Sci. Technol. 2015, 5, 24412448.

(28) Kang, K. H.; Hong, U. G.; Bang, Y.; Choi, J. H.; Kim, J. K.; Lee, J. K.; Han, S. J.; Song, I. K. Hydrogenation of succinic acid to 1,4- butanediol over $\mathrm{Re}-\mathrm{Ru}$ bimetallic catalysts supported on mesoporous carbon. Appl. Catal., A 2015, 490, 153-162.

(29) Hong, U. G.; Hwang, S.; Seo, J. G.; Lee, J.; Song, I. K. Hydrogenation of succinic acid to g-butyrolactone (GBL) over palladium catalyst supported on alumina xerogel: Effect of acid density of the catalyst. J. Ind. Eng. Chem. 2011, 17, 316-320.

(30) Tapin, B.; Epron, F.; Especel, C.; Ly, B. K.; Pinel, C.; Besson, M. Study of Monometallic $\mathrm{Pd} / \mathrm{TiO}_{2}$ Catalysts for the Hydrogenation of Succinic Acid in Aqueous Phase. ACS Catal. 2013, 3, 2327-2335.

(31) Zhang, C.; Chen, L.; Cheng, H.; Zhu, X.; Qi, Z. Atomically dispersed Pd catalysts for the selective hydrogenation of succinic acid to $\gamma$-butyrolactone. Catal. Today 2016, 276, 55-61.

(32) Di, X.; Li, C.; Zhang, B.; Qi, J.; Li, W.; Su, D.; Liang, C. Role of $\mathrm{Re}$ and $\mathrm{Ru}$ in $\mathrm{Re}-\mathrm{Ru} / \mathrm{C}$ bimetallic catalysts for the aqueous hydrogenation of succinic acid. Ind. Eng. Chem. Res. 2017, 56, $4672-4683$

(33) Di, X.; Li, C.; Lafaye, G.; Especel, C.; Epron, F.; Liang, C. Influence of Re-M interactions in Re-M/C bimetallic catalysts prepared by microwave-assisted thermolytic method on aqueousphase hydrogenation of succinic acid. Catal. Sci. Technol. 2017, 7, $5212-5223$

(34) Shao, Z.; Li, C.; Di, X.; Xiao, A.; Liang, C. Aqueous-Phase Hydrogenation of Succinic Acid to $\gamma$-Butyrolactone and Tetrahydrofuran over $\mathrm{Pd} / \mathrm{C}, \mathrm{Re} / \mathrm{C}$, and $\mathrm{Pd}-\mathrm{Re} / \mathrm{C}$ Catalysts. Ind. Eng. Chem. Res. 2014, 53, 9638-9645.

(35) Kang, K. H.; Hong, U. G.; Jun, J. O.; Song, J. H.; Bang, Y.; Choi, J. H.; Han, S. H.; Song, I. K. Hydrogenation of succinic acid to $\gamma$-butyrolactone and 1,4-butanediol over mesoporous rheniumcopper-carbon composite catalyst. J. Mol. Catal. A: Chem. 2014, 395, 234-242.

(36) Tapin, B.; Epron, F.; Especel, C.; Ly, B. K.; Pinel, C.; Besson, $\mathrm{M}$. Influence of the Re introduction method onto $\mathrm{Pd} / \mathrm{TiO} 2$ catalysts for the selective hydrogenation of succinic acid in aqueous-phase. Catal. Today 2014, 235, 127-133.

(37) Schüth, F.; Ward, M. D.; Buriak, J. M. Common Pitfalls of Catalysis Manuscripts Submitted to Chemistry of Materials. Chem. Mater. 2018, 30 (11), 3599-3600.

(38) Kumar, A. P.; Kumar, B. P.; Kumar, A. B. V. K.; Huy, B. T.; Lee, Y. I. Preparation of palladium nanoparticles on alumina surface by chemical co-precipitation method and catalytic applications. Appl. Surf. Sci. 2013, 265, 500-509.

(39) Kuang, D.; Fang, Y.; Liu, H.; Frommen, C.; Fenske, D. Fabrication of boehmite $\mathrm{AlOOH}$ and $\gamma-\mathrm{Al}_{2} \mathrm{O}_{3}$ nanotubes via a soft solution route. J. Mater. Chem. 2003, 13, 660-662.

(40) Padovan, D.; Al-Nayili, A.; Hammond, C. Bifunctional Lewis and Brønsted acidic zeolites permit the continuous production of biorenewable furanic ethers. Green Chem. 2017, 19, 2846-2854.

(41) Al-Nayili, A.; Yakabi, K.; Hammond, C. J. Mater. Chem. A 2016, 4, 1373-1382.

(42) Hammond, C. Intensification studies of heterogeneous catalysts: probing and overcoming catalyst deactivation during liquid phase operation. Green Chem. 2017, 19, 2711-2728.

(43) Sádaba, I.; López Granados, M.; Riisager, A.; Taarning, E. Deactivation of solid catalysts in liquid media: the case of leaching of active sites in biomass conversion reactions. Green Chem. 2015, 17, $4133-4145$

(44) Héroguel, F.; Rozmysłowicz, B.; Luterbacher, J. S. Improving Heterogeneous Catalyst Stability for Liquid-phase Biomass Conversion and Reforming. Chimia 2015, 69 (10), 582-591.

(45) Tarantino, G.; Hammond, C. Catalytic Formation of C(sp3)-F bonds via Heterogeneous Photocatalysis. ACS Catal. 2018, 8, 1032110330.

(46) Kragten, D. D.; van Santen, R. A.; Crawford, M. K.; Provine, W. D.; Lerou, J. J. A Spectroscopic Study of the Homogeneous Catalytic Conversion of Ethylene to Vinyl Acetate by Palladium Acetate. Inorg. Chem. 1999, 38, 331-339.

(47) Kresse, G.; Furthmüller, J. Efficient Iterative Schemes for $A b$ Initio Total-Energy Calculations Using a Plane-Wave Basis Se. Phys. Rev. B: Condens. Matter Mater. Phys. 1996, 54, 11169-11186. 
(48) Kresse, G.; Furthmüller, J. Efficiency of Ab-Initio Total Energy Calculations for Metals and Semiconductors Using a Plane-Wave Basis Set. Comput. Mater. Sci. 1996, 6, 15-50.

(49) Kresse, G.; Hafner, J. Ab Initio Molecular Dynamics for OpenShell Transition Metals. Phys. Rev. B: Condens. Matter Mater. Phys. 1993, 48, 13115-13118.

(50) Kresse, G.; Hafner, J. Norm-Conserving and Ultrasoft Pseudopotentials for First-Row and Transition Elements. J. Phys.: Condens. Matter 1994, 6, 8245-8257.

(51) Perdew, J. P.; Burke, K.; Ernzerhof, M. Generalized Gradient Approximation Made Simple. Phys. Rev. Lett. 1996, 77, 3865-3868.

(52) Blöchl, P. E. Projector Augmented-Wave Method. Phys. Rev. B: Condens. Matter Mater. Phys. 1994, 50, 17953-17979.

(53) Grimme, S. Semiempirical GGA-Type Density Functional Constructed with a Long-Range Dispersion Correction. J. Comput. Chem. 2006, 27, 1787-1799. 